\title{
A New Example of Nanotechnology Applied to Minimally Processed Fruit: The Case of Fresh-Cut Melon
}

\author{
Alessandra Danza, Amalia Conte, Marcella Mastromatteo and Matteo Alessandro Del Nobile* \\ Department of Agriculture Sciences, Food and Environment, University of Foggia, via Napoli, 25-71122 Foggia, Italy
}

\begin{abstract}
The effects of silver nanoparticles (Ag-MMT) incorporated into an alginate-based coating applied to fresh-cut melon (Cucumismelo L.) were assessed on the product shelf life. Different concentrations of Ag-MMT nanoparticles were tested in coated melon that was packaged in an oriented polypropylene-based bag and stored at $5^{\circ} \mathrm{C}$. Results showed that the active coating was effective from the microbiological and the sensory point of view, if compared to the uncoated fruit that rapidly lost the characteristics responsible for fruit acceptance. A significant shelf life prolongation was recorded from less more than 3 days of the control samples to 11 days of coated fruit, thus promoting further investigation on Ag- MMT coating as valid preservation strategy.
\end{abstract}

Keywords: Silver nanoparticles; Coating; Fresh-cut melon; Shelf life

\section{Introduction}

Nanotechnology is an emerging technology also in food science where the interest for manufacturing new materials at the nanoscale level is growing [1]. Among the different types of nanoparticles (NPs), silver ones (AgNPs) have proved to be very effective as thesecompounds generally exert high antimicrobial activity against both Gram-positive and Gram- negative bacteria, such as methicillin resistant $S$. aureus [2] and E. coli, P. aeruginosa and S. faecalis [3]. The research in food science has exploited the nanotechnology to also developnew packaging materials with improved antimicrobial properties. In this context, a new class of antimicrobial systems has been generated from inorganic phyllosilicate clays, such as montmorillonite (MMT), which constitute a support for AgNPs. According to Bouwmeester [4], nanotechnologies currently applied to food can be divided in different food production phases, from processing where NPs may appear in suspension or emulsion, to preservation and packaging. As a fact, NPs can be engineered as food additives or supplements for functionalized foods, such as nano-delivery systems [5,6] build from peptide, carbohydrate or lipid monomers [7-9]. On the other hand, some examples have been also found as NPs applied for preservation aims. Costa et al. [10] reported a significant shelf life prolongation of fresh fruit salad obtained with a new packaging system incorporating Ag-MMT as active compounds. The same authors also reported a significant shelf life prolongation of fresh-cut carrots treated with Ag-MMT [11]. Incoronato et al. [12] applied AgNPs to Fiordilatte cheese, thus demonstrating a significant enhancement of the fresh dairy product quality stored in the active packaging. Fresh-cut fruit and vegetables are increasingly available on supermarket shelves. The operations to obtain fresh-cut produce (washing, peeling and cutting) generally promote a faster physiological deterioration, biochemical change and microbial degradation [13]. Melon (Cucumismelo) in particular, is one of the most consumed fresh-cut fruit due to its attractive color, good flavor, refreshing properties and its high content of vitamins, mineral salts and fibers. Unfortunately, the shelf life of this product is strongly affected by the high amount of water and sugars which constitute an ideal substrate for microbial proliferation, besides the almost neutral $\mathrm{pH}$ does not constitute a natural barrier against pathogens. Moreover, melons are grown on the ground, then to direct contact with any organic fertilizers and the surface uneven and porous allows microorganisms to adhere very well, then cross contamination of the pulp at the time of cutting can easily occur. These reasons make necessary to develop valid preservation techniques to prevent the deteriorative processes that occur during processing and storage (microbial spoilage, desiccation, discoloration or browning, textural changes and development of off-odor). Edible coatings may reduce fresh-cut fruit deterioration, being able to control the respiration rate and the water loss and also serving as carriers of active compounds [14-16]. Moreover, the use of coatings as carriers of silver represents a viable approach to avoid the direct contact of nanoparticles with food $[12,17]$. The aim of this work was to evaluate the influence of alginate coating loaded with silver- montmorillonite nanoparticles (Ag-MMT) on shelf life of fresh-cut melon. To assess the influence of the active coating on the fresh-cut produce, both microbial and sensory quality decay were assessed during a proper refrigerated storage period.

\section{Materials and Methods}

\section{Fruit preparation}

'Proteo' Melons (Cucumis melon L.) were kindly provided by a local farm (Futuragri, Foggia, Italy) at a commercial stage of ripeness, transported within $2 \mathrm{~h}$ directly from the field to the laboratory under refrigerated conditions and stored in a ventilated room at $4^{\circ} \mathrm{C}$ prior to processing. For the samples preparation a protocol including proper washing steps wasfollowed. The whole fruit was firstly washed with tap water to remove residuals, dipped for $5 \mathrm{~min}$ in chlorinated water $\left(20 \mathrm{ml} \mathrm{L}^{-1}\right)$ and finally washed in a 50\% water-ethanol solution for the same time. Afterward, the whole fruit was air-dried for $10 \mathrm{~min}$ at room temperature $\left(23^{\circ} \mathrm{C}\right)$, peeled, cut longitudinally using a manual vegetable cutter into slices of about $25 \mathrm{~mm}$ thickness and the pulp was further cut in trapezoidal sections $(12 \mathrm{~g})$. The coating solutions were prepared by dissolving food-grade sodium alginate powder $(2 \% \mathrm{w} / \mathrm{v})$ (Farmalabor, Canosa, Italy) in distilled water while heating on a stirring hot plate for $10 \mathrm{~min}$ at $70^{\circ} \mathrm{C}$ until the mixture became clear. Silvermontmorillonite nanoparticles (Ag-MMT) were kindly provided by

${ }^{*}$ Corresonding author: Matteo Alessandro Del Nobile, Department of Agriculture Sciences, Food and Environment, University of Foggia, via Napoli, 25 - 71122 Foggia, Italy, Tel: +39 0881589 242; E-mail: matteo.delnobile@unifg.it

Received March 06, 2015; Accepted March 18, 2015; Published March 25, 2015

Citation: Danza A, Conte A, Mastromatteo M, Nobile MAD (2015) A New Example of Nanotechnology Applied to Minimally Processed Fruit: The Case of Fresh-Cut Melon. J Food Process Technol 6: 439. doi:10.4172/2157-7110.1000439

Copyright: $\odot 2015$ Danza A, et al. This is an open-access article distributed under the terms of the Creative Commons Attribution License, which permits unrestricted use, distribution, and reproduction in any medium, provided the original author and source are credited. 
the National Research Council of Naples (IPCB) that prepared the nano composite systems as also reported in another work [18]. The AgMMT nanoparticles were in the range of $10-40 \mathrm{~nm}$ and were added to the coating solution in concentrations of 150,250 and $500 \mathrm{ppm}(\mathrm{w} / \mathrm{v})$, by stirring the solution for $30 \mathrm{~min}$. Melon pieces were first dipped into each active solution for $2 \mathrm{~min}$, the excess solution was allowed to drip off before submerging each fruit piece in a calcium chloride solution $(5 \% \mathrm{w} / \mathrm{w})$ for $5 \mathrm{~min}$ to promote the alginate gel forming. All samples were dried at room temperature for $2 \mathrm{~min}$. A proper amount of coated samples corresponding to $100 \mathrm{~g}$ was packaged in an oriented polypropylene-based bag of $40 \mu \mathrm{m}$ thickness. The bags were $250 \mathrm{~mm} \times$ $250 \mathrm{~mm}$ long, with an Oxygen Transmission Rate (OTR) of $1171.72 \pm$ $9.58 \mathrm{cc} /\left(\mathrm{m}^{2}\right.$.day $)$ at $23^{\circ} \mathrm{C}$ and $0 \% \mathrm{RH}$. The bags were hermetically sealed by means of a thermal sealer (Gandus sealers, Milan, Italy) under air conditions and then stored at $5^{\circ} \mathrm{C}$ for the entire observation period (19 days). As reference sample, uncoated fresh-cut melon was also packaged. In the current work a coating without any active compounds was not taken into account because preliminary tests on the same cultivar melon highlighted that the behaviors of coated and uncoated samples were very similar. For the sake of clarity, the investigated samples were labeled as follows: CTRL (uncoated fresh-cut melon), Coat-150 (fresh-cut melon coated with $150 \mathrm{mg}$ of Ag-MMT), Coat250 (fresh-cut melon coated with $250 \mathrm{mg}$ of Ag-MMT) and Coat-500 (fresh-cut melon coated with $500 \mathrm{mg}$ of Ag-MMT).

\section{Microbiological analyses and $\mathrm{pH}$ determination}

Viable cell loads of main spoilage microorganisms were monitored for the entire observation period. For microbiological analyses, about $10 \mathrm{~g}$ of sample was aseptically removed from each package, placed in a stomacher bag, diluted with $0.9 \% \mathrm{NaCl}$ solution and homogenized with a Stomacher LAB Blender 400 (Pbi International, Milan, Italy). Decimal dilutions were carried out using the same diluent. Mesophiles and psychrotrophs were determined on Plate Count Agar (PCA) with incubation at $30^{\circ} \mathrm{C}$ for $24-48 \mathrm{~h}$ and $7^{\circ} \mathrm{C}$ for 10 days, respectively. For coliforms, Violet Red Bile Agar (VRBA) was used and plates were incubated at $37^{\circ} \mathrm{C}$ for $18-24 \mathrm{~h}$. Yeasts andmoulds were determined on Sabouraud Dextrose Agar (SDA),supplemented with chloramphenicol $\left(0.1 \mathrm{~g} \mathrm{~L}^{-1}\right)$ (C. Erba, Milan, Italy) with incubation at $25^{\circ} \mathrm{C}$ for $48 \mathrm{~h}$ and 5 days, respectively. deManRogosa Sharpe agar (MRS), added with 0.17 $\mathrm{g} / \mathrm{L}$ cycloheximide (Sigma-Aldrich, Milan, Italy) incubated at $30^{\circ} \mathrm{C}$ for 2-4 days for lactic acid bacteria (LAB). All the media used were from Oxoid (Milan, Italy). The microbiological analyses were carried out twice on two different batches. The measurement of $\mathrm{pH}$ on the first homogenized dilution of the fresh-cut melon was performed twice on two different batches, by using a pH-meter (Crison, Barcelona, Spain).

\section{Sensory analyses}

During storage, fruit samples were submitted to a panel of 7 trained evaluators in order to assess the sensory attributes. According to a similar procedure reported in the literature [19] a 9-point scale was used to define the intensity of odor, color, firmness and overall quality. This last parameter has to be considered as an average of the other sensory attribute (i.e., color, odor, and firmness) as evaluated by each panelist. A score equal to 5 was used as the threshold for fruit acceptability. To determine the Sensory Acceptability Limit (SAL) of the investigated fresh-cut produce, a first order kinetic equation [20] was fitted to the experimental data:

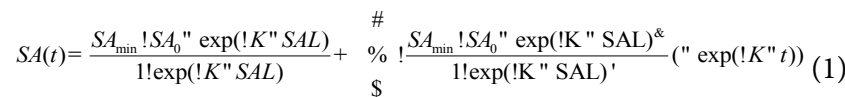

where $\mathrm{SA}(\mathrm{t})$ is the fresh-cut melon overall quality at time $t, k$ is the kinetic constant, $\mathrm{SA}$ is the initial value of the melon overall quality, $\mathrm{SA}_{\min }$ is the limit for fresh-cut produce acceptability, SAL is the sensory acceptability limit (i.e., the time at which $\mathrm{SA}(\mathrm{t})$ is equal to $\mathrm{SA}_{\min }$ ), and $t$ is the storage time.

\section{Statistical analysis}

The values of the microbial cell loads and the SAL values relative to the sensory quality were compared by one-way ANOVA, respectively. A Duncan's multiple range test, with the option of homogeneous groups $(\mathrm{p}<0.05)$, was used to determine significance among differences. Statistical 7.1 for Windows (StatSoft Inc., Tulsa, OK, USA) was used for this purpose.

\section{Results and Discussion}

\section{Microbial quality}

Table 1 reports the cell load of mesophylic and psychotropic bacteria at 0 and 8 days of sampling for all the investigated samples. A concentration of $5 \times 10^{7} \mathrm{CFU} / \mathrm{g}$ of total mesophilic bacteria was selected as threshold for microbial acceptability, as imposed by the French Regulation [21]. As can be seen from the table, the initial cell load accounted for about $2 \log$ CFU/g. A gradual increase in mesophilic population was found for the uncoated melon (CTRL), until reaching the microbial threshold within a few days of storage (5 days). Differently, a low cell load was detected in all the active coated samples where the microbial threshold was never reached. Anyhow, a certain differences among the active coated samples were found. In fact, while fresh-cut melon coated with the two lowest concentrations of AgMMT (Coat-150 and Coat-250) reached a microbial concentration of about 6.89 and $5.57 \log \mathrm{CFU} / \mathrm{g}$, respectively, on the $8^{\text {th }}$ day of storage, the Coat-500 sample presented a cell load of $6.64 \mathrm{log}$ CFU/g on day $13^{\text {th }}$ and reached the threshold on day $19^{\text {th }}(7.79 \log \mathrm{CFU} / \mathrm{g})$. This result confirmed the correlation between efficacy and Ag-MMT nanoparticles concentration, as also demonstrated in other applications of silver nanoparticles to fresh fruit [11]. The antimicrobial activity can be related to the silver ions released. When the silver ions enter the bacterial cells by penetrating through the cell wall turn the DNA into a condensed form to react with the thiol group proteins and provoke the cell death [22]. Morones et al. [23] studied the effect of silver nanoparticles on $E$. Coli growth and demonstrated that at concentration less above $75 \mu \mathrm{g} /$ $\mathrm{ml}$ there was no bacterial growth. As regard the psychotropic bacteria, a trend similar to that found for the mesophilic count was recorded (data not shown). For the other investigated microbial groups (yeast, moulds and coliforms) a very low proliferation (about $4 \log \mathrm{CFU} / \mathrm{g}$ ), by one or two log cycles below the uncoated sample (CTRL) was recorded throughout the storage in all the active coated fruits.

The $\mathrm{pH}$ values showed a constant trend during the entire observation period, accounting for about 6 in all the active coated samples and about 4.9 in the uncoated sample.

\section{Sensory quality}

Figure 1 shows the evolution during storage of the fresh-cut melon overall quality for all the investigated samples. SAL values were listed in Table 2 . The solid horizontal line is the overall quality threshold (score $=5$ ). As can be inferred from Figure 1, in accordance to the microbiological results, the uncoated sample (CTRL) rapidly falls down below the threshold, due to the fast color changes caused by dehydration. In fact, color is a critical quality parameter of fresh-cut fruit since cutting operations may often lead to enzymatic browning. 


\begin{tabular}{|c|c|c|c|c|}
\hline Samples & Mesophiles & & \multicolumn{2}{|c|}{ Psycrotrophs } \\
\hline & $\log c f u / \mathrm{g}_{\text {initial }}$ & $\log \mathrm{cfu} / \mathrm{g}_{8 \text { days }}$ & $\log \mathrm{cfu} / \mathrm{g}_{\text {initial }}$ & $\log \mathrm{cfu} / \mathrm{g}_{8 \text { days }}$ \\
\hline Coat-150 & $2.00^{\mathrm{a}} \pm 0.00$ & $6.89^{\mathrm{a}} \pm 0.33$ & $2.89^{\mathrm{a}} \pm 1.54$ & $6.94^{\mathrm{a}} \pm 0.27$ \\
\hline Coat-250 & $2.00^{\mathrm{a}} \pm 0.00$ & $5.57^{\mathrm{b}} \pm 0.68$ & $2.00^{\mathrm{a}} \pm 0.00$ & $5.47^{\mathrm{b}} \pm 0.51$ \\
\hline Coat-500 & $2.00^{\mathrm{a}} \pm 0.00$ & $4.97^{\mathrm{b}} \pm 0.21$ & $2.00^{\mathrm{a}} \pm 0.00$ & $4.73^{\mathrm{b}} \pm 0.38$ \\
\hline CTRL & $2.23^{\mathrm{a}} \pm 0.40$ & $7.79^{\mathrm{c}} \pm 0.06$ & $2.26^{\mathrm{a}} \pm 0.38$ & $7.82^{\mathrm{c}} \pm 0.03$ \\
\hline
\end{tabular}

Mean values \pm standard deviation.

a-bMeans in the same column followed by different superscript upper cases are significantly different $(\mathrm{P}<0.05)$.

Table 1: Mesophilic and psychrotrophic initial and final bacterial count (log cfu/g) of fresh-cut melon samples.

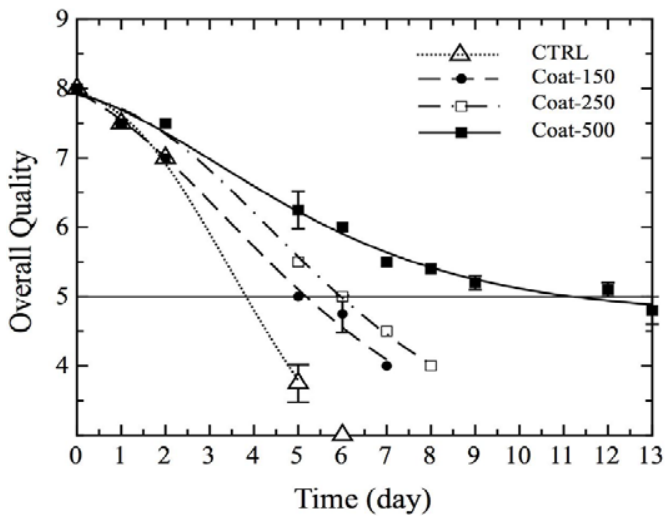

Figure 1: Overall quality decay of all fresh-cut melon samples. The curves are the best fit of Eq. (1) to the experimental data.

\begin{tabular}{|c|c|}
\hline Samples & SAL $=$ Shelf life (day) \\
\hline Coat-150 & $5.17^{\mathrm{a}} \pm 0.18$ \\
\hline Coat-250 & $5.95^{\mathrm{a}} \pm 0.18$ \\
\hline Coat-500 & $11.18^{\mathrm{c}} \pm 0.18$ \\
\hline CTRL & $3.82^{\mathrm{b}} \pm 0.21$ \\
\hline
\end{tabular}

${ }^{a-c}$ Data in the column with different superscript letters are significantly different $(\mathrm{P}<0.05)$.

Table 2: Sensory acceptability limit $(S A L)$ and shelf life (mean $\pm S D$ ) of fresh-cut melon samples.

In the literature, some authors reported the positive effect of the incorporation of additives (ascorbic acid, calcium chloride and sorbic acid) into edible coatings for controlling browning phenomena [2426]. In the case under investigation, the active coated samples did not show any color modification until the first week of storage and were also preserved in terms of humidity. As can be seen from data listed in Table 2, some differences can be observed between them. For the Coat-150 and Coat-250 samples, the SAL value (5 days) was due to a general spoiling in terms of consistency. These findings are in accordance to the most studies carried out to evaluate the influence of processing and storage conditions on the quality perception of freshcut fruits [27] where the visual quality decreased below the threshold of marketability after about 1 week of storage. The slicing operations result in a dramatic firmness decay of tissues fruit; moreover, the transformation of proto-pectin to water-soluble pectin, the decrease in cellulose crystallinity, the diffusion of sugar to the intercellular spaces [28], the loss of turgor and the ion movement from the cell wall [29] may be also responsible for softening. Differently, the Coat-500 sample showed values of sensory quality above the threshold (score $=5$ ) for about 11 days, thus demonstrating that the highest silver concentration contributed to maintain an acceptable odor, color and firmness for a prolonged storage period, compared to the other samples. The shelf life determination is generally intended as a consequence of both microbial and sensory quality decay kinetic. Therefore, in the current work, by comparing the microbial loads and the sensory acceptability, the shelf life of melon coincided with the SAL values (Table 2). As can be seen, statistical significant differences in shelf life were found between uncoated and coated samples. In particular, the active coating improved the shelf life of melon by increasing the microbial quality and the sensory acceptability, if compared to the uncoated melon (CTRL). Among the coated samples, the Coat-500 recorded better results by assuring a sensory acceptability until the $11^{\text {th }}$ day that represents an interesting finding if compared to the uncoated fruit sample.

\section{Conclusions}

In this work the influence of an alginate coating loaded with different concentration of Ag- MMT nanoparticles on shelf life of fresh-cut melon was studied. To this aim, microbiological and sensory attributes were observed during the storage. Results suggested that the sensory parameters played a major role in determining the product acceptability because the coating treatment with Ag-MMT controlled the microbial growth and the melon did not overlap the microbiological limit imposed for fresh-cut fruit and vegetables. The combined use of alginate coating and silver nanoparticles allows maintaining good melon quality, thus prolonging the shelf life to about 11 days, with respect to the uncoated samples (3 days).

\section{Acknowledgement}

The authors thank the National Research Council of Naples (InstitutodeiPolimeri, Compositie Biomateriali-IPCB, Ing. G.G. Buonocore) to kindly provide the silver nanoparticles.

\section{References}

1. Albrecht MA, Evan CW, Raston CL (2006) Green chemistry and the health implications of nanoparticles. Green Chemistry 8: 417-32.

2. Panacek A, Kvitek L, Prucek R, Kolar M, Vecerova R, et al. (2006) Silver colloid nanoparticles: synthesis, characterization, and their antibacterial activity. Journal of Physical Chemistry 110: 16248-53.

3. Castellano JJ, Shafii SM, Ko F, Donate G, Wright TE, et al. (2007) Comparative evaluation of silver-containing antimicrobial dressings and drugs. International Wound Journal 4: 114-22.

4. Bouwmeester H, Dekkers S, Noordam MY, Hagens WI, Bulder A, et al. (2009) Review of health safety aspects of nanotechnologies in food production. Regulatory Toxicology and Pharmacology 53: 52-62.

5. Letchford K, Burt H (2007) A review of the formation and classification of amphiphilic block copolymer nanoparticulate structures: micelles, nanospheres, nanocapsules and polymersomes. European Journal of Pharmaceutics and Biopharmaceutics 65: 259-269.

6. Taylor TM, Davidson PM, Bruce BD, Weiss J (2005) Liposomal nanocapsules in food science and agriculture. Critical Reviews in Food Science and Nutrition 45: 587-605.

7. Chen LY, Remondetto GE, Subirade M (2006) Food protein-based materials as nutraceutical delivery systems. Trends in Food Science and Technology 17: 272-283.

8. Graveland-Bikker JF, de Kruif CG (2006) Unique milk protein based nanotubes: Food and nanotechnology meet. Trends in Food Science and Technology 17: 196-203.

9. Mozafari MR, Flanagan J, Matia-Merino L, Awati A, Omri A, et al. (2006) Recent trends in the lipid-based nanoencapsulation of antioxidants and their role in foods. Journal of the Science of Food and Agriculture 86: 2038-2045.

10. Costa C, Conte A, Buonocore GG, DelNobile MA (2011) Antimicrobial silvermontmorillonite nanoparticles to prolong the shelf life of fresh fruit salad. International Journal of Food Microbiology 148: 164-167. 
Citation: Danza A, Conte A, Mastromatteo M, Nobile MAD (2015) A New Example of Nanotechnology Applied to Minimally Processed Fruit: The Case of Fresh-Cut Melon. J Food Process Technol 6: 439. doi:10.4172/2157-7110.1000439

11. Costa C, Conte A, Buonocore GG, Lavorgna M, Del Nobile MA (2012) Calciumalginate coating loaded with silver-montmorillonite nanoparticles to prolong the shelf-life of fresh-cut carrots. Food Research International 48: 164-169.

12. Incoronato AL, Conte A, Buonocore GG, Del Nobile MA (2011) Agar hydroge with silver nanoparticles to prolong the shelf life of Fior di Latte cheese. Journal of Dairy Science 94: 1697-1704

13. Ragaert P, Devlieghere F, Debevere J (2007) Role of microbiological and physiological spoilage mechanisms during storage of minimally processed vegetables. Postharvest Biology and Technology 44: 185-194.

14. Durango AM, Soares NFF, Andrade NJ (2006) Microbiological evaluation of an edible antimicrobial coating on minimally processed carrots. Food Control 17: $336-341$

15. Oms-Oliu G, Soliva-Fortuny R, Martin-Belloso O (2008) Using polysaccharidebased edible coatings to enhance quality and antioxidant properties of fresh-cut melon. LWT-Food Science and Technology 41: 1862-1870.

16. Benitez S, Achaerandio I, Sepulcre F, Pujola M (2013) Aloe vera based edible coatings improve the quality of minimally processed Hayward kiwifruit. Postharvest Biology and Technology 81: 29-36.

17. Gammariello D, Conte A, Buonocore GG, Del Nobile MA (2011) Bio-based nanocomposite coating to preserve quality of Fior di latte cheese. Journal of Dairy Science 94: 5298-5304.

18. Incoronato AL, Buonocore GG, Conte A, Lavorgna M, Del Nobile MA (2010) Active systems based on silver/montmorillonite nanoparticles embedded into bio-based polymer matrices for packaging applications. Journal of Food Protection 73: 2256-2262.

19. Bai JH, Saftner RA, Watada AE, Lee YS (2011) Modified Atmosphere Maintains Quality of Fresh-cut Cantaloupe (Cucumismelo L.). Journal of Food Science 66: 1207-1211.
20. Conte A, Scrocco C, Brescia I, Del Nobile MA (2009) Packaging strategies to prolong the shelf life of minimally processed lampascioni (Muscaricomosum). Journal of Food Engineering 90: 199-206.

21. Ministere de l'Economie des Finances et du Budget (1988) Marche consommation, Produitsvegetauxprets a l'emploidits de la "IVemme Gamme": Guide de bonnespratiquehygieniques. Journal Officiel de la Republique Française 1621: 1-29.

22. Mahendra R, Alka Y, Aniket G (2009) Silver nanoparticles as a new generation of antimicrobials. Biotechnology Advances 27: 76-83.

23. Morones JR, Elechiguerra JL, Camacho A, Ramirez JT, Holt K, et al. (2005) The bactericidal effect of silver nanoparticles. Nanotechnology 16: 2346-53.

24. Wong DWS, Camirand WM, Pavlath AE (1994) Development of edible coatings for minimally processed fruits and vegetables. Edible coatings and films to improve food quality. Technomic Publishing, Lancaster, PA.

25. Lee JY, Park HJ, Lee CY, Choi WY (2003) Extending shelf-life of minimally processed apples with edible coatings and antibrowning agents. LWT-Food Science and Technology 36: 323-329.

26. Olivas GI, Rodriguez JJ, Barbosa-Canovas GV (2003) Edible coatings composed of methylcellulose stearic acid, and additives to preserve quality of pear wedges. Journal of Food Processing and Preservation 27: 299-320.

27. Soliva-Fortuny RC, Martın-Belloso O (2003) New advances in extending the shelf-life of fresh-cut fruits: a review. Trends in Food Science and Technology 14: 341-353.

28. Bolin HR, Huxsoll CC (1989) Storage stability of minimally processed fruit Journal of Food Processing and Preservation 13: 281-292.

29. Poovaiah BW (1986) Role of calcium in prolonging storage life of fruits and vegetables. Food Technology 40: 86-89. 